\title{
Effects of online Advertising on Consumers
}

\author{
Gitanjali Kalia, Assistant Professor and Dr. Ashutosh Mishra, Dean, \\ School of Mass Communication, Chitkara University, Punjab
}

\begin{abstract}
Purpose of the study: The study would help the advertisers to understand to what extent the online advertising is beneficial. This study will bring facts that how advertiser's use social sites to make their products popular. This study will also be beneficial for the research scholars to analyze as to how consumers perceive the online advertisements and what are their parameters for purchasing stuff from the online sites.

Research methodology:

A survey method was used for collecting the data and questionnaire was used as a tool for conducting a survey among 500 respondents who are net savvy. Questionnaire was designed on the basis of parameters studied on the home page of the websites on regular basis. For designing the questionnaire and collecting the data online Google forms was used. The options in the questionnaire are based on the data collected from content analysis to study the response of the netizens towards them. Therefore, the data was shifted to Microsoft excel and converted to pie and bar graphs for graphically presentation. Thus the graphical presentation has also been derived from the Google forms and Microsoft excel.

Conclusions: The research concluded that respondents prefer rectangular banner and skyscraper advertisements that too designed in big picture and copy heavy layouts. They notice the online advertisements of ecommerce sites and mobile phones as compared to any other product and prefer those ads whose utility or functions are displayed.

Online ads placed above the mast head and on the right side of the homepage gains the maximum attention towards it. Advertisements displayed vibrant colors and promotional offers attract the netizens.

Significance: The study will be beneficial for the marketers and web designers to understand the criteria of the netizens for considering the online advertisements and liking them.
\end{abstract}

Keywords: Online advertising, netizens, homepage, ads, advertisements, product.

\section{INTRODUCTION}

Online advertising refers to the type of marketing strategy that involves the use of internet for promotion of products by delivering the marketing messages to the larger consumers. It includes delivering ads to internet users via websites, e-mail, ad supported software's, text messaging and internet enabled cell phones.

Philip Kotler in Marketing management Millenium Edition mention that the internet population is younger, more affluent, and better educated and they easily find their way onto the internet, the cyberspace population is becoming more mainstream and diverse. In on-line marketing, it is the consumer, not the marketer, who gives permission and controls the interaction. Internet consumers have around-the-clock access to varied information sources, making them better informed and more discerning shoppers.

\section{REVIEW OF LITERATURE}

With the increased adoption of ad fission of the internet, world wide web is becoming gradually a standard advertisement platform. The web is offering business advertisements world with rich media tool, interactive series and global reach. (Dr Surender Kumar Gupta, 2013) Though the online activities has increased over the period of past five years, netizens find e- shopping more convenient and time saving but there is a space for improvement of delivery services and advertising the web products and services for long term success concluded Yuping Liu,Ph.D. In contrast to this, the other school of thought believes that web advertising creates negative and positive perceptions among the consumers. They perceive web advertising as portraying too much of sex and on the other hand as strong source of information and is a good thing to look at.(Norzalita Abd Aziz, Ahmad Azmi M. Ariffin(2010). It is interesting to study that where so much of research has been conducted regarding future of online advertising and the consumer behaviour towards it, less focussed has been given to internet advertisements and their layouts that are carried on the homepages of different websites.

Though people enjoy looking at internet advertisements, its formativeness and utility for making behavioural purchasing decisions also plays a key role (Ann.E. Schlosser, Sharon Shavit \& Alaina(1999)

According to one of the research conducted on internet advertisements, it was concluded that voluntary and exposure ad formats like banner and text ads are more likely to be cognitively avoided since it is an automatic,

DOI: 10.9790/0837-2109013541 $\quad$ www.iosrjournals.org $35 \mid$ Page


sub conscious process that occurs in parallel with browsing activity and does not require any behavioural action by consumer. Another research by Xavier Dreze \& Francis Xavier Husherr(July 2003) also supported the above research by concluding people actually avoid looking at banner ads during online activities.

Intrusive ad formats like Pop ups that interrupt browsing activity and demands immediate response are more likely to be physically avoided by closing them.(Chatterjee Patrali,2008)

In another response on context to internet ads it was concluded that banner and pop up ads are both annoying and extensively intrusive in nature. Banner ads are mostly noticed due to their relevancy and location on the page and should include bright colors, interactivity, graphics, videos, logos, sizes and discounts(Kozen Kavin,2006)In one of the research by Scott Mcloy, Andrea Everard, Dennis Galleta, Peter Polak(2004) title 'A study of the effects of online advertising: A focus on Pop up and In-line ads' it was concluded that pop up ads reduces a person's retention of both sites and ad content more severely than in-line ads.

Therefore, it can be seen that though much research has been done on internet advertising, consumer behaviour and ecommerce sites, very less emphasis has been given laid on the layouts of the web pages and the advertisements on it and their layouts. Hence, the exploratory study endeavors' to analyze the following research areas:

$\checkmark$ What type of online advertisements consumer notices on popular websites.

$\checkmark$ Are online advertisements placed at top of homepage and big and flashy really attracts consumers.

$\checkmark$ Does the persuasion technique through catchy words and offers attract probable consumers?

$\checkmark$ To know what type of advertisement layout is broadly adopted by the websites.

$\checkmark$ To know what type of product category advertisements are displayed on homepages.

$\checkmark$ To know the layout style of websites with reference to online advertisements and the netizens liking.

\section{RESEARCH METHODOLOGY}

Hence, questionnaire was used as a tool for conducting a survey among 500 respondents who are net savvy. Questionnaire was designed on the basis of parameters adopted by the home page of the websites on regular basis. For designing the questionnaire, Google forms was used. The options in the questionnaire are based on the data collected from content analysis to study the response of the netizens towards them. Therefore, the graphically presentation has also been derived from the Google forms.

\section{Data Analysis:}

\section{GRAPH NO.1}

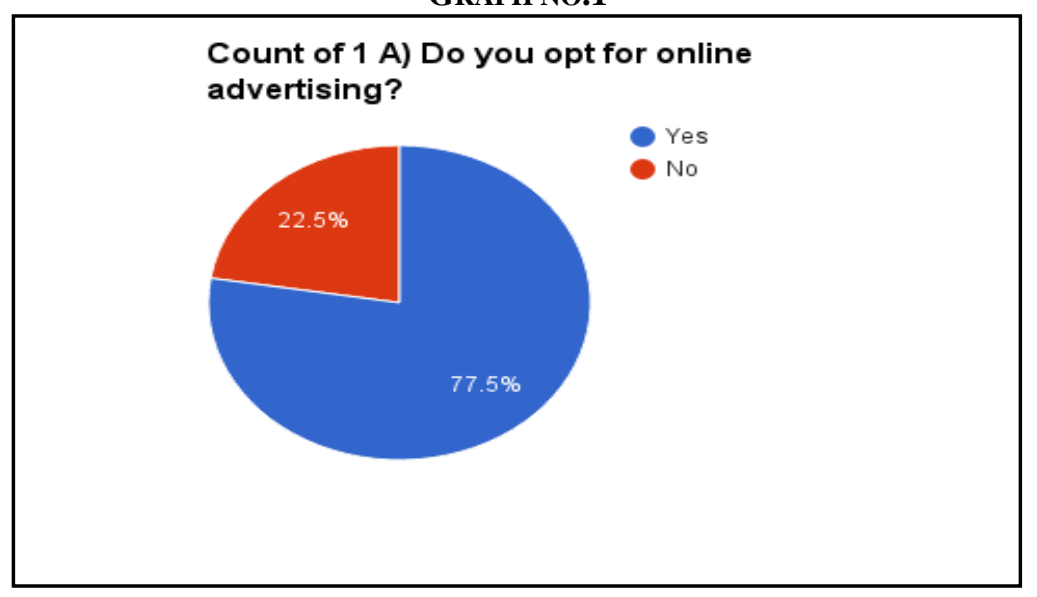

Graph 1 shows that $77.5 \%$ netizens do prefer online advertising whereas there is still $22.5 \%$ respondents who don't opt for online advertising and prefer traditional shopping over it.

\section{GRAPH No.2}




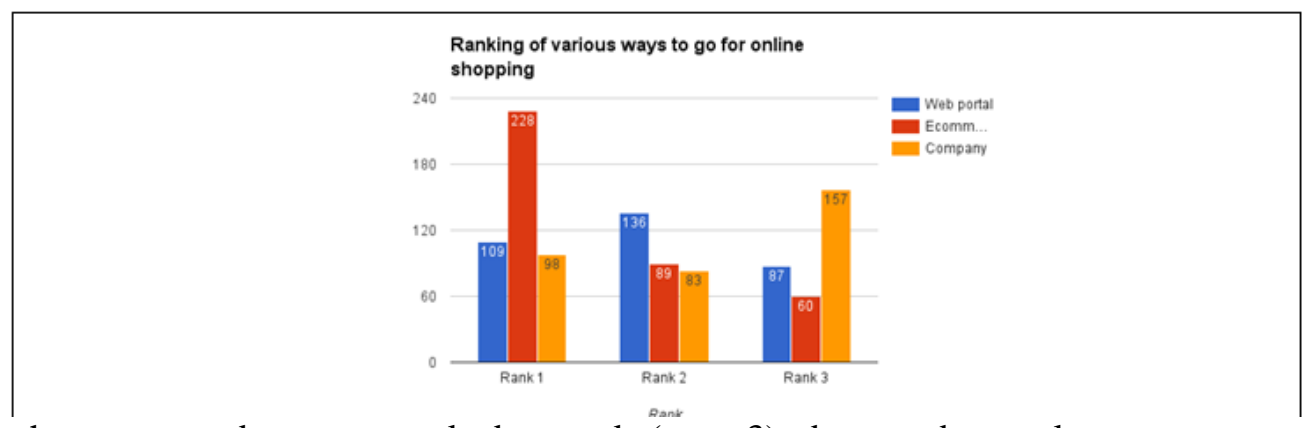

Graph 2 shows respondents were asked to rank (upto 3) about web portals, ecommerce sites and company websites in response to their online shopping. It was not mandatory to rank 1, 2 and 3 but they were allowed to rank only $1,1 \& 2$ or upto 3 , so that data gathered is shown on the above Graph No.2.

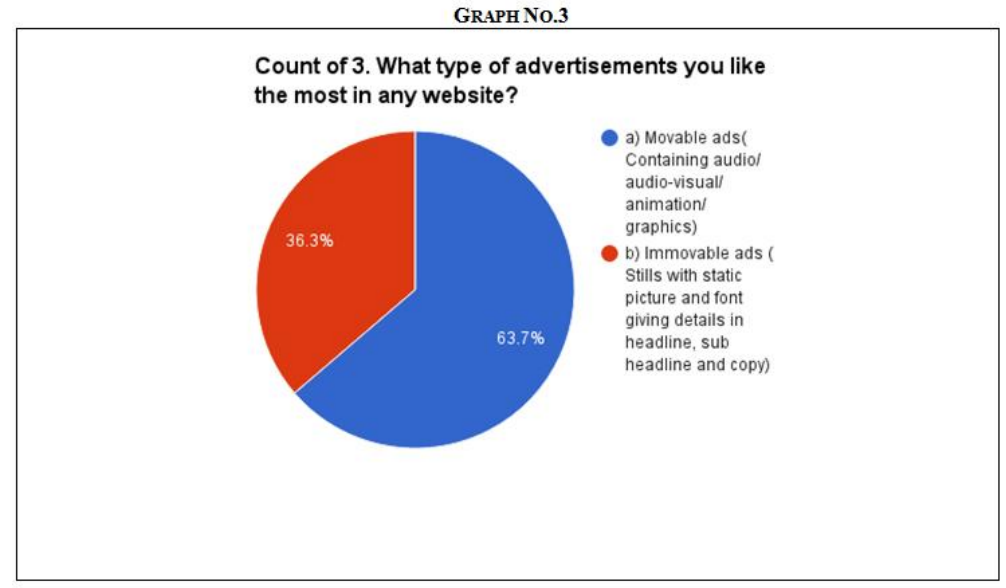

Graph 3 shows that $64 \%$ of respondents like movable ads i.e. those ads that are visually apeealing and contains animations and graphics whereas nearly $36 \%$ of the netizens also like immovable ads on the website homepage.

\section{GRAPH No.4}

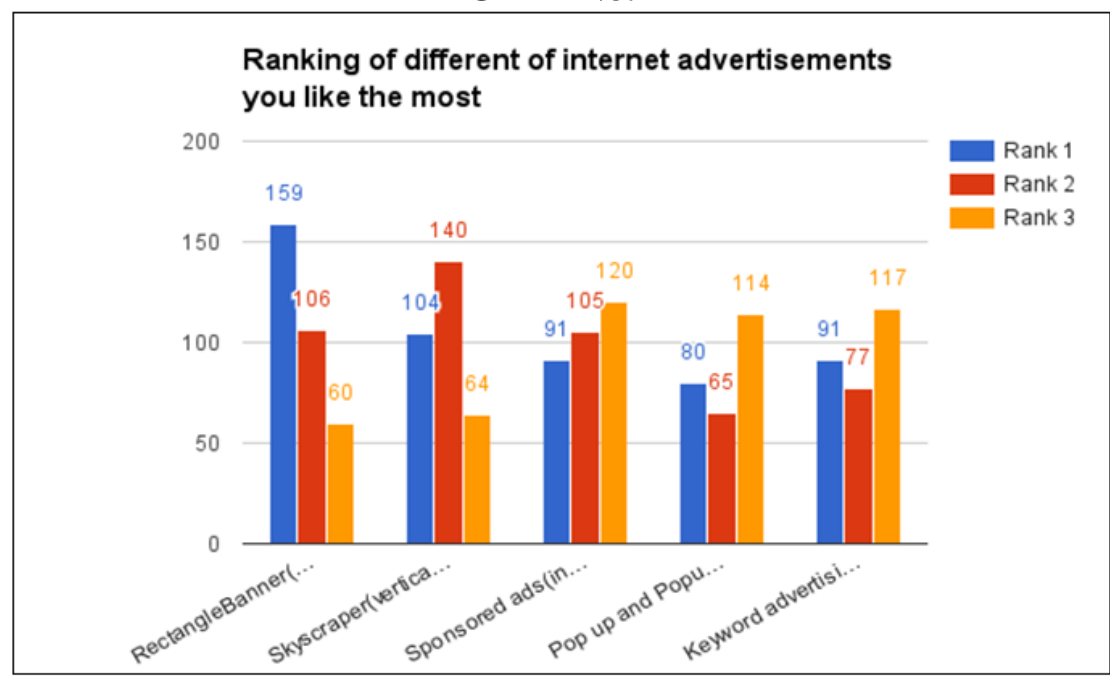

Graph 4 it can be seen from the above graph that 159 respondents preferred rectangle banner advertisements as rank 1, followed by Skyscraper (vertical ads) liked by 140 respondents and 120 people gave rank 3 to sponsored ads.

\section{GRAPH No.5}




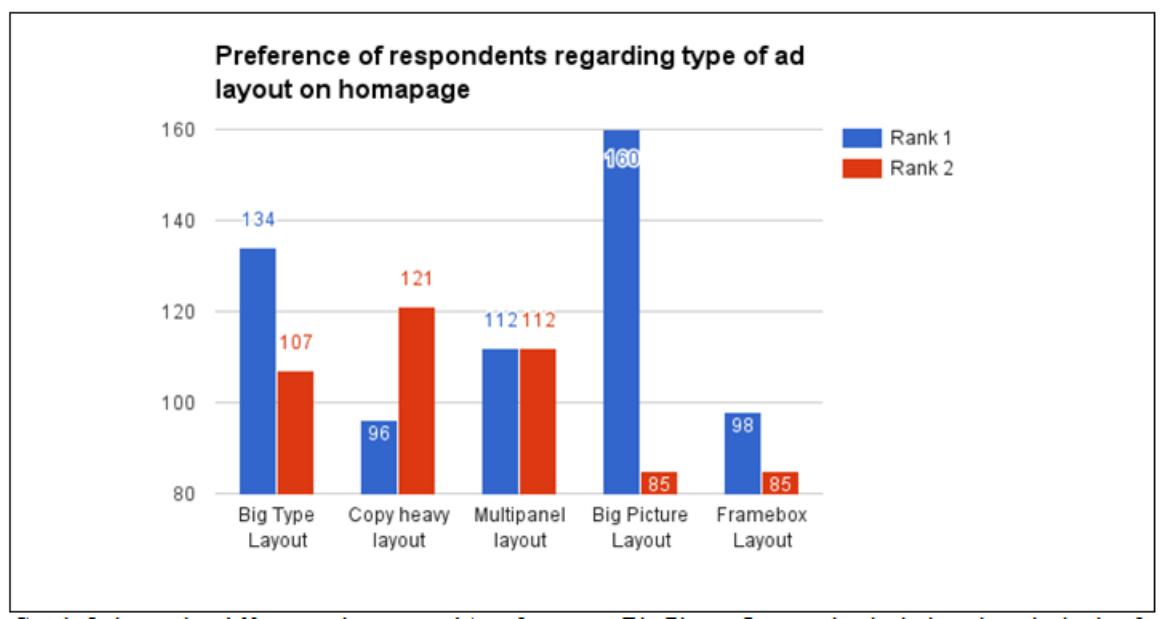

Graph 5 shows that 160 respondents gave $1^{\text {st }}$ preference to Big Picture Layout that is designed on the basis of displaying larger image on the advertisement and 121 respondents gave $2^{\text {nd }}$ preference to Copy heavy layout in which the textual portion is more as compared to the images displayed.

\section{GRAPH No.6}

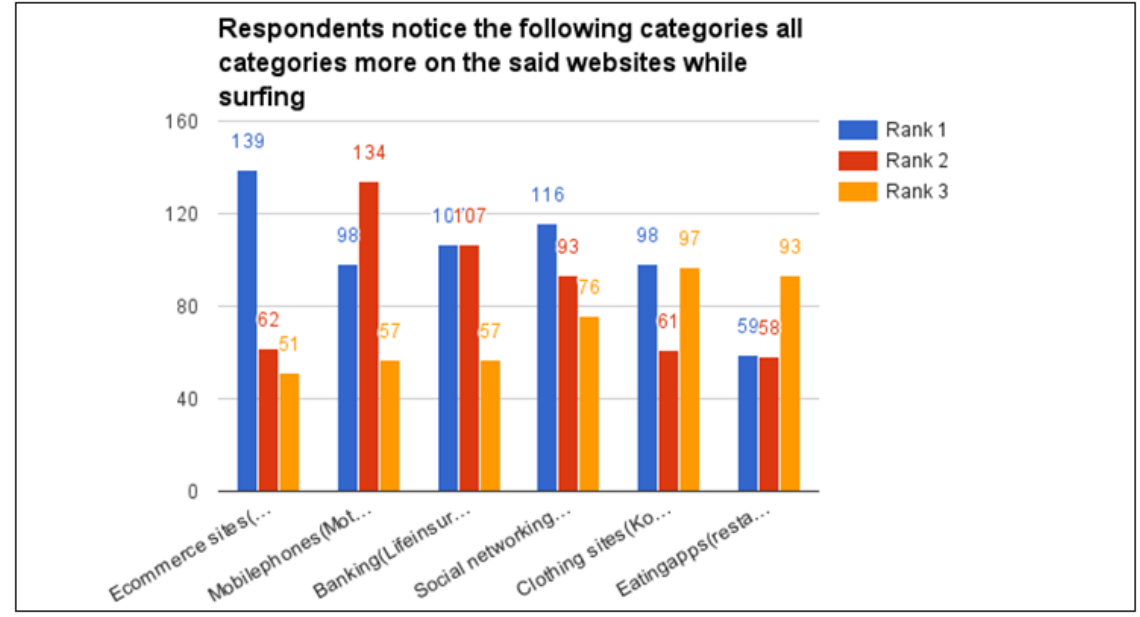

Graph 6 shows that 139 respondents has given first rank to ecommerce sites which means that they mainly shop from ecommerce sites, followed by the online advertisements of mobile phones with 134 respondents giving it rank 2 whereas only 97 respondents gave clothing sites as their third preference.

\section{GRAPH No.7}

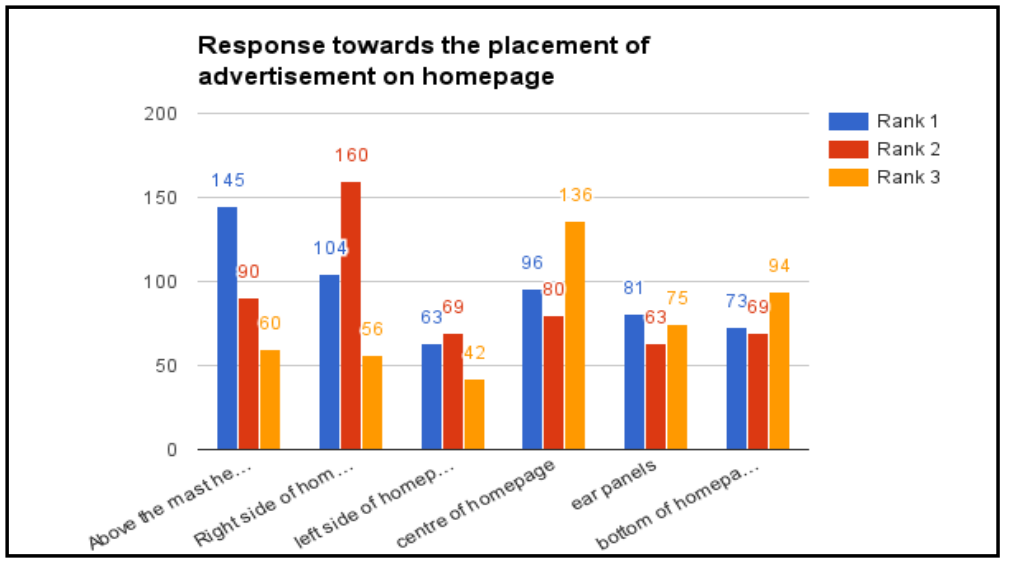

Graph 7 shows that 145 respondents gave first rank to the advertisements placed above the mast head followed by their preference towards the online ads placed on the right side with 160 respondents giving it Rank 2. Last but not the least; third rank was given to online advertisements placed at the centre of the homepage. 
GRAPH No.8

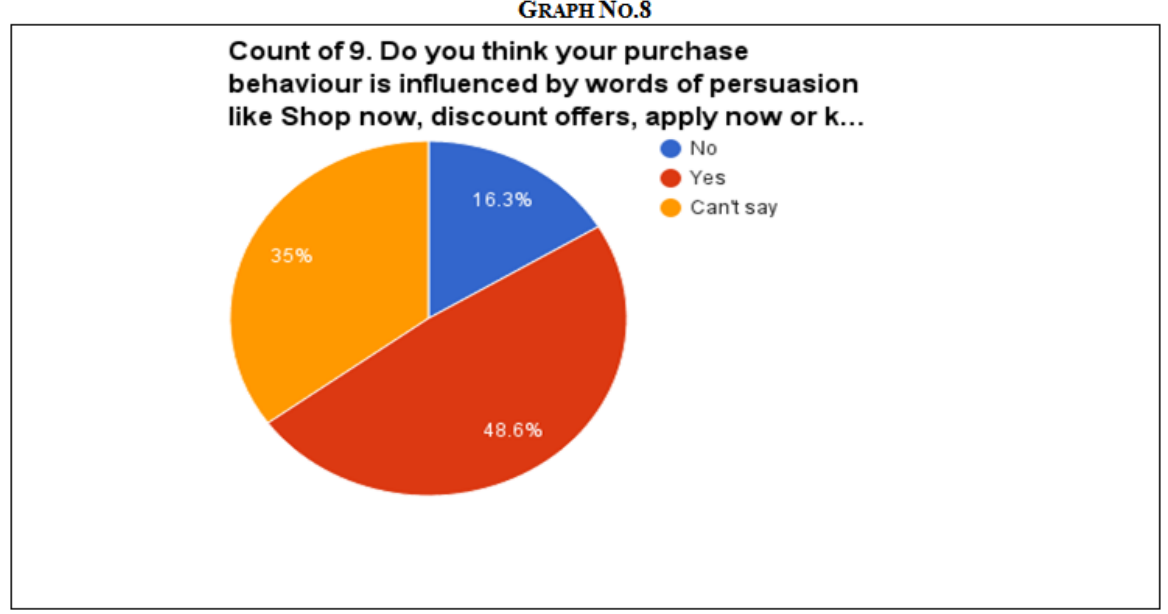

Graph 8 mentioned above shows that $48.6 \%$ of respondents believe that words like buy now, apply now, etc. do persuade them to make purchases whereas $16.3 \%$ directly refused to agree with it and the rest percentage of respondents can't give their opinion about it.

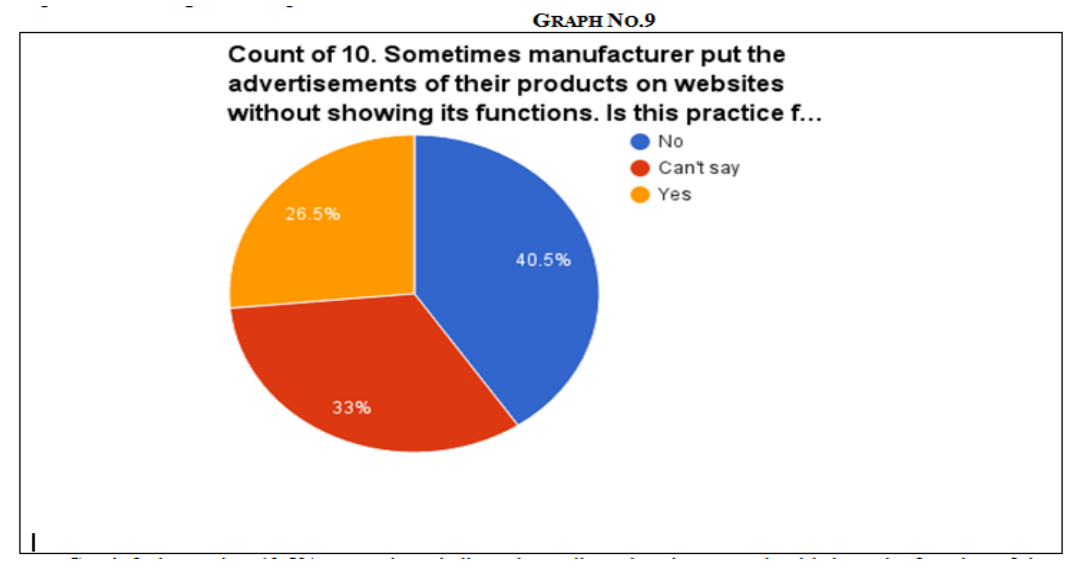

Graph 9 shows that $40.5 \%$ respondents believe that online advertisements should show the function of the product as well whereas $26.5 \%$ of respondents are pretty fine with the practice. Still $33 \%$ of netizens didn't comment about it.

Graph No.10

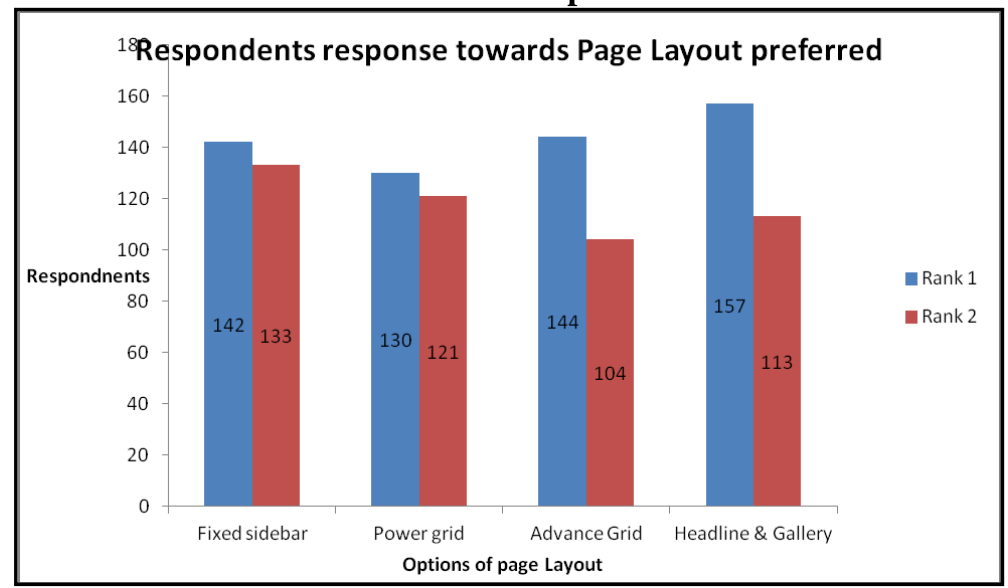

Graph 10 Headline and Gallery layout was given Rank 1 by 157 respondents whereas 133 respondents gave second rank to Fixed Sidebar layout.

\section{Graph No.11}




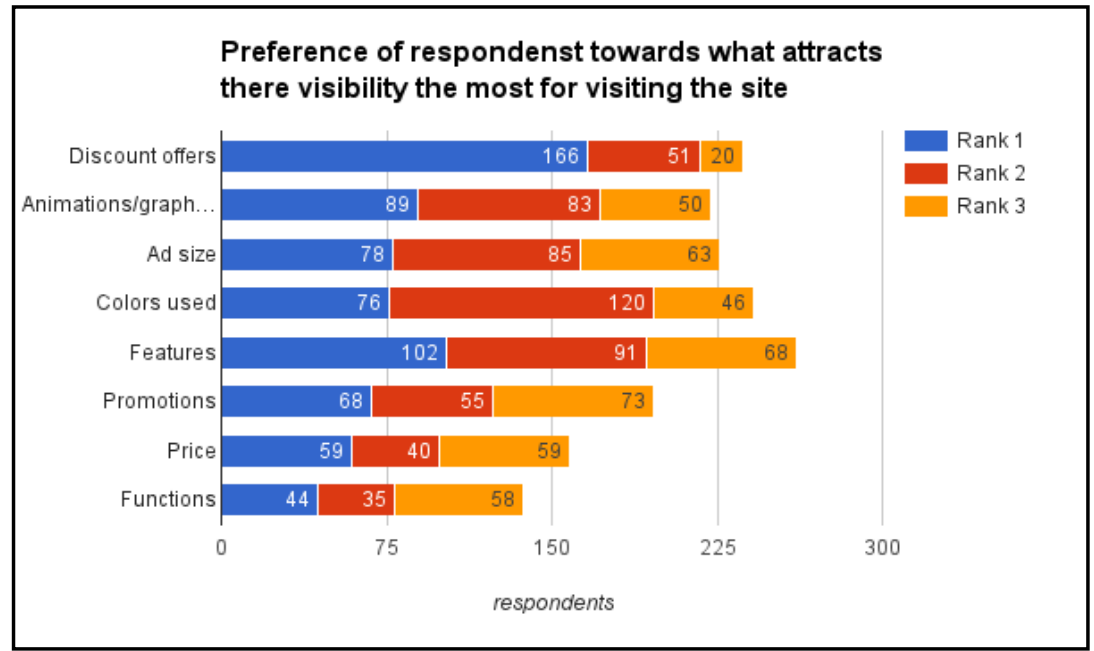

Graph 11 shows that 166 respondents consider notice discount offers on online advertisements by giving them $1^{\text {st }}$ rank followed by 120 respondents that feel that colors attract them the most on online ads. $3^{\text {rd }}$ rank was given to promotions with 78 respondents agreeing to it.

\section{Conclusion:}

After conducting the survey among 500 respondents and analyzing the data, the following conclusions can be drawn:

$\checkmark$ The result show that majority of people do opt for online advertising but prefer ecommerce sites for buying as compared to web portals and company website.

$\checkmark$ In comparison to movable and immovable ads, netizen prefer movable advertisements that include visuals, music, graphics and animations.

$\checkmark$ The survey also concludes that some netizens do like still online ads that are designed in Big Picture Layout for the tangible products but for service oriented products, respondents prefer Copy Heavy Layout ads.

$\checkmark$ Though various types of internet advertisements appear on the website but respondents prefer rectangular banner advertisements followed by skyscraper ads that are in vertical format.

$\checkmark$ Majority of respondents who took survey responded that they agree or strongly agree to the statement that websites contain more advertisements than content.

$\checkmark$ With the reference to the websites studied, respondents have noticed online ads of ecommerce sites like Jabong, Flipkart, Amazon, etc. in majority followed by ads of mobile phones.

$\checkmark$ In a survey about the placement of the online ads on websites, the ads placed above the mast head and on the right side of the homepage attract the maximum attention towards it.

$\checkmark$ While researching for people reaction to the persuasive words, it was found that words of persuasion like shop now, buy now, discount, apply and many such words do influence the purchasing behaviour of the consumer.

$\checkmark$ There are many immovable online ads on the website that do not show the functions and utility of the product and people also responded in dislike for such practice, thus preferring movable ads over immovable ads.

$\checkmark$ Respondents prefer Fixed sidebar and Advance grid pattern for the layout of the websites.

$\checkmark$ Advertisements displaying discount offers attract the netizen immediately followed by other features of the ads like colors used in the ads and promotions provided on the online ads of the products.

\section{REFERENCES:}

[1] AHN, E., \& EDWARDS, S. M. (2002). Brand attitude versus click-through response to banner ads. Paper presented at the American Academy of Advertising.

[2] AZIZ NORZALITA ABD, ARIFFIN AHMAD AZMI M.(2010) Exploring consumers attitude towards Web advertising and its influence on Web Ad usage in Malaysia'; Pg. 55-66

[3] BAKSHI GAURAV AND GUPTA K DR. SURENDER (2013) 'Online advertising and its impact on Consumer buying behaviour'. International Journal of Research in Finance \& Marketing, Vol. 3, Issue 1 (ISSN 2231-5985)

[4] BARBARA K. KAYE AND NORMAN MEDOFF. (2001)Just a Click Away: Advertising on the Internet, MASSACHUSETTS: ALLYN AND BACON.

[5] BORREL CATHERINE (2010)'Online Consumer Behaviour:Europe' ;Market Development Overview. IAB Europe Research Group. 
[6] BRIGGS, REX AND NIGEL HOLLIS (1997) Advertising on the Web: Is There Response Before ClickThrough? , Journal of Advertising Research, 37, 2, 33-45.

[7] BUSH, A. J., BUSH, V., \& HARRIS, S. (1998). Advertiser perceptions of the Internet as a marketing communications tool. Journal of Advertising Research, 38(2), 17-27.

[8] CHATTERJEE PATRALI (2008)'Are Unclicked ads wasted? Enduring effects of Banner and Pop-up Ad exposures on Brand memory and attitudes' Journal of Electronic Commerce Research, VOL 9, NO 1, 2008

[9] CHO, CHANG-HOAN AND CHEON, HONGSIK JOHN (2004), "Why do People Avoid Advertising on the Internet?"Journal of Advertising, 33(4), 89-97.

[10] DOOLIN, B., DILlON, S., THOMPSON, F., CORNER,J. L.( 2005). Perceived risk, the internet shopping experience and online purchasing behaviour: A New Zealand perspective. Journal of Global Information Management, 13(2), 66-88.

[11] DREZE, XAVIER AND FRANCOIS HUSSHERR, (2003)'Internet Advertising: Is Anybody Watching,' Journal of Interactive Marketing, Vol. 17, No. 4:8-23.

[12] DUNCAN MATHEW (2011)'Online Advertising: Identifying different types of web advertising and its impact on consumer buying behavior' Elon University

[13] GONG, W., \& MADDOX, L. M. (2003). Measuring Web advertising effectiveness in China. Journal of Advertising Research, 43(1), 34-49.

[14] HANAFIZADEH, P., \&BEHBOUDI, M. (2008). Internet advertising. New Opportunity for Promotion. 1st ed,. Termeh Publication, Tehran. Iran. ISBN, 978-964-978-100-6.

[15] HOODA DR. SANJAY AND AGGRAWAL MR. SANDEEP (2012) 'Consumer Behaviour towards Emarketing: A study of Jaipur Consumers'. Journal of Arts, Science \& Commerce. Vol.- III, Issue 2(2), Pg.107

[16] HUNG HUANG JEN AND CHUN YANG YI (2010) 'Gender differences in adolescents' online shopping motivations’ African Journal of Business Management Vol. 4(6), pp. 849-857, June 2010

[17] JOHNSON, M., SLACK, M., \& KEANE, P (1999) Inside the mind of the online consumer -- increasing advertising effectiveness.

[18] KELLY LOUISE (2008); 'Teenager Perception of advertising in the online social networking environment'. A Research Thesis.

[19] KUMARI PALLAVI (2012)' Changing Purcahse Behaviour of Indian Customers' Journal of Economics and ManagementVol.1 Issue 8, November 2012, ISSN 2278-0629

[20] LIU YUPING 'Integrating Consumer Preferences into Online Advertising:Drivers of Consumer Tendency to engage in online advertising'.A Research Thesis.

[21] LODORFOS GEORGE N., TROSTERND TOM A., WHITEWORTH CHRIS (2006) 'E-commerce, attitude and behaviour in the online commodities market'; special edition on Consumer Satisfaction-A Global Perspective

[22] LI, H., \& COYLE, J. R. (1997). Determinants of purchases on the World Wide Web. Paper presented at the American Academy of Advertising.

[23] LUK S., W. CHAN, AND E. L , ( 2002), "The content of internet advertisements and its impact on awareness and selling performance", Journal of marketing management, 18(7/8), 693- 720.

[24] MOHAMMED BANY ASHRAF; ALKUBISE MOHAMMED (2012) 'How do Online Advertisements Affects Consumer Purchasing Intention: Empirical Evidence from a Developing Country'. European Journal of Business and Management. ISSN 2222-1905 (Paper) ISSN 2222-2839 (Online) Vol. 4, No.7.

[25] PRIYANKA SRIVASTAVA(2012)'A study on the Impact of the Online advertising on Consumer Behaviour(With special reference to E-mails)'.International Journal of Engineering and management Sciences.Vol 3(4):Pg.461-465

[26] RASTOGI KUMAR ANKUR (2010)'A study of Indian Online Consumers \& their Buying Behaviour' International Research Journal, July 2010 ISSN- 0975-3486 RNI: RAJBIL 2009/30097 VOL I *ISSUE 10 